5. JAR-FCL, 1.245: Type- og klasserettigheter gyldighet, forlengelse og fornyelse http://www.lovdata.no/cgi-wift/ldles?doc=/sf/sf/ sf-20091120-1407.html (26.9.2011).

6. JAR-FCL, JAR-FCL 3.025 Gyldighet av sertifikater og rettigheter http://www.lovdata.no/cgi-wift/ Idles?doc=/sf/sf/sf-20080619-0617.htm (26.9.2011).

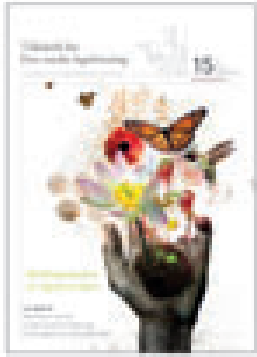

\section{Legemiddelindustrien og dobbeltmoralen}

I Tidsskriftet nr. 15/2011 forklarer Karita Bekkemellem pent hvorfor legemiddelindustrien sluttet å sponse reise på kongresser for norske leger (1). En av årsakene til dette var at de mente sponsing av deltakelse på kongresser kunne gjøre at leger ikke forskrev beste medisin for sine pasienter, men i stedet skrev ut medisin fra det firmaet som hadde sponset dem.

Jeg har praktisert i Norge i 30 år og jeg har vært på mange kongresser som ble betalt av firmaer. Men jeg har aldri utskrevet en eneste medisin som jeg ikke var overbevist om var den beste for pasienten, uansett med hvilket firma jeg har reist og hvor god middag og vin jeg har fått. At den farmasøytiske industri sluttet å invitere leger på viktige faglige kongresser, tror jeg kan ha negativ betydning for mange legers evne til å oppdatere sin kunnskap. Det er nemlig mange som ikke blir sponset av sin arbeidsgiver og som ikke selv har råd til å delta på medisinske kongresser. Legemiddelindustrien har de siste årene vært opptatt av at legene som reiser på kongresser ikke skal ha bra hotell og rimelig bra mat, og de har gitt dem billigste vin, men samtidig har den medisinske industri drevet meget aggressiv markedsføring av sine medisinske produkter. Hvorfor har ikke Legemiddelindustrien noe imot at medisinske firmaer inviterer leger på sine egne symposier og at firmarepresentanter kommer til legekontoret? På slike møter blir legene mest hjernevasket av medisinske firmaer, som prøver å forklare hvor godt produkt de har og ofte at deres produkt er mye bedre enn de andres. Jeg har opplevd flere ganger at små studier plutselig ble store studier, og negative studier ble omgjort til positive av medisinske firmaer.

Hvis Legemiddelindustrien virkelig vil være helt sikre på at de ikke påvirker leger til å skrive ut medisiner, bør de slutte med besøk av legemiddelrepresentanter på legekontorer, slutte å invitere på sine egne symposier som veldig ofte har lavt medisinsk nivå, slutte å sende brosjyrer til legene og kun annonsere sine egne produkter i Tidsskiftet.

\section{Grzegorz Gradek Bergen}

Grzegorz Gradek (f. 1953) er privatpraktiserende kardiolog og pulmonolog ved Hjerte og Lungesenteret, Bergen.

Oppgitte interessekonflikter: Forfatteren har fått betalt reiser til kongresser av den farmasøytiske industri.

\section{Litteratur}

1. Bekkemellem K. Åpenhet om samarbeid og deling av kunnskap. Tidsskr Nor Legeforen 2011. 131: 1528

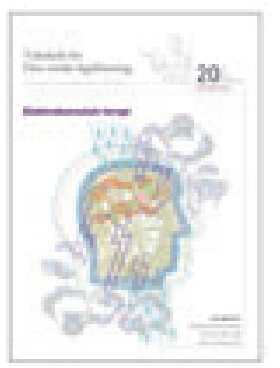

\section{Moros refleks fremdeles viktig verktøy}

I Tidsskriftet nr. 20/2011 stiller Arne Tveit spørsmål ved nødvendigheten av Moros refleks ved seksukerskontrollen (1). Refleksen inngår i det refleksbatteriet som brukes til å vurdere barnets nevrologiske utvikling de første levemånedene. Refleksen ble første gang beskrevet i 1918 av Ernst Moro, en av Europas ledende barneleger i begynnelsen av det forrige århundre (2): «Når barnet ligger på undersøkelsesbenken og man banker med hendene på begge sider av puten, følger det en rask strekke-abduksjon av begge armene som deretter umiddelbart nærmer seg til hverandre i en adduksjon» (3).

Før jeg utløser refleksen (vanligvis slik Arne Tveit gjør det) pleier jeg på forhånd med et smil å si til barnet at «nå skal vi se om vi kan skremme deg litt», slik at foreldrene skal være forberedt på barnets reaksjon. Jeg har ikke inntrykk av at foreldrene har reagert negativt på undersøkelsen. Moros refleks utløses av vestibulær stimulering og kan derfor også utløses ved bevegelse av hele kroppen uten dorsalfleksjon av bare hodet (4). Hvor godt man lykkes $i$ å utløse refleksen, avhenger av en rekke forhold, bl.a. barnets våkenhetsgrad (4). Ofte ser man at barnet spontant utfører en Moros reaksjon i forbindelse med at man kler av barnet, ved kraftige lyder eller ved andre eksterne stimuli. Har jeg først sett en slik spontan Moros refleks og barnet ellers virker friskt, gjør jeg sjelden forsøk på også å fremprovosere refleksen. Moros refleks sier imidlertid også noe om det perifere nervesystemet og armene. Dersom det har vært en vanskelig skulderforløsning, med mistanke om claviculafraktur eller pleksusskade, vil påvisning av en sterkt asymmetrisk refleks være et viktig funn.

Moros refleks hører til gruppen av primitive reflekser som taper seg i løpet av de første 2-3 månedene, og som kan være uttrykk for patologi dersom den består lenger ut i spedbarnsalderen enn ved 4-5månedersalderen. Ved seksukersalder bør barnet fortsatt ha en Moros refleks, selv om den kan være svakere enn ved fødselen, og selv om det som nevnt over, er mange andre normale forhold som påvirker hvor lett det er å utløse refleksen. På dette tidspunktet vil også en generell undersøkelse, anamnestiske opplysninger om ernæring, vektoppgang samt følelse av kontakt mellom barn og foreldre i stor grad bidra til vurderingen av barnet. Hvis det generelle inntrykket ved seks uker er at barnet utvikler seg normalt, ville jeg ikke gjøre store anstrengelser for å få utløst Moros refleks. Den bør likevel ikke strykes fra listen over diagnostiske verktøy ved seksukersalderen.

Dag Bratlid

Barne- og ungdomsklinikken St. Olavs hospital

Dag Bratlid (f. 1944) er professor I og overlege ved Nyfødt intensivavdelingen, Barne- og ungdomsklinikken, St. Olavs hospital.

Ingen oppgitte interessekonflikter.

\section{Litteratur \\ 1. Tveit A. Overflødig undersøkelse? Tidsskr Nor Legeforen 2011; 131: 1990 \\ 2. Weirick A, Hoffmann GF. Ernst Moro (1874-1951) - a great pediatric career started at the rise of uni- versity-based pediatric research but was curtailed in the shadows of Nazi laws. Eur j Pediatr 2005; 164: 599-606. \\ 3. Moro E. Das erste Trimenon. Muench Med Wschr 1918: 42: 1147-50. \\ 4. Rönnqvist $L$. A critical examination of the Moro response in newborn infants - symmetry, state relation, underlying mechanisms. Neuropsycho- logia 1995: 33: 713-26.}

\section{Var Sveits tilbakestående?}

Takk til Aina Schiøtz for en artig artikkel i Tidsskriftet nr. 16/2011 (1). Det er imidlertid et par punkter som jeg har lyst til å kommentere fordi de vakte minner om min sveitstiske mor som et par ganger kom ulykkelig hjem etter å ha blitt verbalt ganske så hatsk angrepet av kjente kvinner i det norske politiske miljø: «Er De fra Sveits! Ja det går ikke an at de ikke har stemmerett, det er en skam.» 
Du skriver «vi er vant til å betrakte Sveits som noe tilbakestående når det gjelder kvinners rettigheter» (1). Hvem er «vi»? Denne setningen skriver du i presens: Mener du at du fremdeles betrakter Sveits som noe tilbakestående når det gjelder kvinners rettigheter? Det artige klippet du presenterte tyder ikke på «tilbakeståendehet».

Om man kjenner litt til forholdene i Sveits og hva de (tidligere) mektige «Frauenverein» oppnådde, tror jeg de var ganske flinke til å ta seg av kvinnepolitikk, familiepolitikk og barn og unges forhold. Jeg vil ikke dømme om hvem som var «best» eller «tilbakestående». Og som bare halvt norsk vil jeg ikke være med på den utrolig utbredte tanke at Norge leder i så meget. («Det er typisk norsk å være god»). Du skriver «Sveitsiske kvinner fikk for eksempel stemmerett først i 1971». Ja, riktig, men kan du nevne flere eksempler?

Før 1971 spurte jeg ofte slektninger om hvordan de i all verden kunne godta ikke å ha stemmerett. Det ble referert to praktiske grunner: nemlig at Sveits har utstrakt bruk av referendum i lokale eller nasjonale saker. En borger må ofte stemme flere ganger i året og med deres sparsommelige sans synes de at en dobling av stemmene ville «bli svært dyrt». Stemmetallet ved disse stadige voteringer - også nå når kvinnene stemmer- er for tiden utrolig lavt, men det er deres problem. Inntil 1970-årene var det også enkelte små kantoner der man fortsatt stemte ved håndsopprekning på torget.

Det argumentet som ikke var offisielt, men som jeg selv har størst tro på, var at de gifte kvinner stort sett ville doble mannens stemme, men at de unge, single i større grad ville velge venstresidens argumenter. Jeg ser det derfor slik at å holde kvinnene utenfor stemmerett var en klassisk høyre/ venstre-konflikt, og jeg er ikke med på ditt «vi» som mener at sveitsere var tilbakestående når det gjelder kvinners rettigheter generelt. Det kan også nevnes at tanken om en internasjonal kvinnedag (8. mars) først ble tenkt i USA i 1909, deretter vedtatt på Kjøbenhavnmøte i 1910 og tiltrådt av Sveits, Tyskland, Østerrike og Danmark året etter. «Vi» ventet til 1915.

Helene Pande

Oslo

Helene Pande (f. 1928) er pensjonert barnelege. Ingen oppgitte interessekonflikter.

\footnotetext{
Litteratur

1. Schiøtz A. Kvinners adgang til medisinstudiet. Tidsskr Nor Legeforen 2011; 131: 1576.
} 